\title{
LOW CARBON RETROFIT: ATTITUDES AND READINESS WITHIN THE SOCIAL HOUSING SECTOR.
}

\section{INTRODUCTION}

Modernisation, retrofit and refurbishment are used interchangeably in the literature (Hong et al, 2009; Jenkins, 2010; Reeves et al, 2009; Bell and Lowe, 2000; Kelly, 2009) to describe the upgrade of a property's physical characteristics to improve its environmental performance. Here, we will use the term sustainable retrofit. Sustainable retrofit includes upgrades to the fabric or systems of a property that may reduce energy use or generate renewable energy.

The UK has a legally binding target to reduce carbon emissions in the UK by $80 \%$ by the year 2050 (HM Government, 2008). The UK housing sector contributes approximately $27 \%$ of these emissions (DECC, 2009) through a number of "derived demand" (Government Office of Science, 2008) activities such as heating and hot water as well as cooking, lighting and use of appliances. The carbon emissions from housing will need to be virtually nil by 2050 (Wetherall et al, 2011), with reliance on renewable energy generation and phasing out of fossil fuels such as natural gas, which accounts for approximately $80 \%$ of domestic fuel consumption, used to generated electricity and on-site combustion through domestic boilers (Swan et al, 2010).

Climate change is one of three objectives of current UK energy policy (DTI, 2006; DTI, 2007). Fuel poverty (Boardman, 2007) is a growing problem, increasing in England from a low of $1.2 \mathrm{~m}$ households in 2003 to approximately $3.5 \mathrm{~m}$ households in 2010 (DECC, 2012a). However, in 1996, 5.1m households were defined as fuel poor, so this is not a new issue. The third policy objective is energy security, which is concerned with the stability of energy supply.

Initially the focus of UK policy was concerned with the performance of new build housing, with approaches such as the Code for Sustainable Homes (CLG, 2006; Lowe and Oreszczyn, 2008) and the Building Regulations (ODPM, 2006; Lowe and Oreszczyn, 2008), which mainly target new build properties. However, the UK housing replacement rate was less than $1 \%$ per annum even at peak construction levels. Approximately $70 \%-80 \%$ of the buildings currently in the housing supply will still be in use in 2050 (Kelly, 2009; Boardman, 2007; Ravetz, 2008), the target date for the UK to have a reduction of $80 \%$ in carbon emissions (HM Government, 2008). With many of these existing buildings having poor energy efficiency (Roberts, 2008), if we are to consider changing the way the domestic sector consumes energy, this places the existing stock very much at the centre of the debate.

In 2010, the previous UK government identified the social housing sector as having a market development role for sustainable retrofit. 
"We said last year that we intended that social housing would continue to show leadership in its environmental performance. There is a real opportunity to use social housing to stimulate the development of the industry needed to make the change described above." (HM Government, 2010a) p7

The incoming coalition government in their Low Carbon Construction Innovation and Growth Report (HM Government 2010), also stated,

“...the use of the social housing stock to kick-start scale retrofit, utilising RMI investment and other funds." (HM Government 2010b) p10

The sustainable retrofit market is emerging and specific activity by Government may be required to effectively upscale the market (van Sandick and Oostra, 2010) to a point where it may be acceptable to owner-occupiers or private landlords, who make up the larger proportion of the housing market. The Government's commitment to building skills and supply chains within the market, alongside policy instruments, recognises the complexity of the problem, identified in market transformation (Killip, 2012) and socio-technical innovation models (Geels, 2005; Swan et al., 2012).

Social housing has the benefit of access to property professionals, who may make more informed decisions, more effectively project-manage and have existing programmes of maintenance and refurbishment of their properties (Jenkins, 2010). Pilot projects of "deep" sustainable retrofit, such as the Technology Strategy Board's Retrofit for the Future programme in the UK (TSB, 2009), were undertaken within the social housing sector. Programmes where the demands for carbon emissions reduction were less stringent than the demonstration programmes, such as the Pay as You Save pilots (DECC, 2011a), Community Energy Savings Programme projects and the European Reconstruction and Development Fund (Wetherill et al, 2012) projects, are dominated by the social housing sector. A recent survey of innovative retrofit projects in the UK identified that virtually all of them were enabled in some way by grant funding (Swan et al, 2012), although this might be driven by the fact that the public sector is more inclined to share knowledge thus skewing the sample.

The government's view that the social housing sector will be used as a test bed to establish supply chains and business models to address the domestic stock, $83 \%$ of which is in private hands, either through owner-occupiers $(67 \%)$ or private landlords $(16 \%)$. This is a developmental requirement for the successful delivery of the recently instigated Green Deal and Energy Company Obligation (ECO) (Guertler, 2012), which are designed to support large-scale retrofit in the UK from 2012/3. However, how the social housing sector views this Governmental perspective needs to be understood.

The Retrofit State of the Nation Survey was undertaken with the social housing sector to identify current attitudes and activities concerning the retrofit agenda. It addressed the perspective of social housing providers regarding sustainable retrofit as an issue, strategic 
intent and activities that are currently being undertaken to improve both the energy efficiency and carbon emissions from the social housing stock.

\section{UK Social Housing Stock and Energy Efficiency}

The UK housing stock contains 26.8 million homes (CLG, 2011; Welsh Assembly Government, 2011; The Scottish Government, 2012; The Northern Ireland Housing Executive, 2012) as shown in table 1. Within England 67\% of houses are owner occupied, $16 \%$ are privately rented and $17 \%$ are social housing (CLG, 2011). Social housing within the UK is defined as housing that is affordable, provided on a needs driven basis where housing provision is not met by the market (CLG, 2011). There are approximately 4.7 million social homes in the UK, $18 \%$ of the total stock, including social housing providers and local authorities.

\section{Table 1 - All Tenures and Social Stock by Country}

The social housing stock is generally better performing in terms of energy efficiency than the whole housing stock. Dwelling energy efficiency in the UK is measured using the Standard Assessment Procedure (SAP) and generates a scale from 1 - 120, with a higher score indicated higher energy efficiency (Hong et al, 2006), although in practical terms the scale is to 100. The English Housing Survey identifies the average SAP rating for the housing stock is 53 in all tenures and 60 in the social stock, indicating a marginally better performance.

The social housing stock has experienced a number of recent upgrade programmes that explain this higher performance (Boardman, 2007). The Decent Homes Programme included a range of fabric and heating improvements that improved the energy performance of stock (Reeves et al, 2009; Power, 2008). 1.4 million homes have benefited from a Decent Homes intervention (NAO, 2010). The energy companies deliver two UK Government programmes that have delivered improvements to the social housing sector - the Carbon Emissions Reduction Target (CERT) and the Communities Energy Saving Programme (CESP). CERT is a programme for energy efficiency, focussing on measures such as loft and cavity wall insulation, for the UK housing stock as a whole (Jenkins, 2010), with some focus on vulnerable households (Druckman and Jackson, 2008). CESP looks at community-wide whole-house sustainable retrofit (Reeves et al, 2009) in areas of deprivation. CERT and CESP will be replaced by the Energy Company Obligation (DECC, 2011b), which has three main components - affordable warmth and carbon saving, which replicate CERT, and the Carbon Saving Communities Obligation (DECC, 2012b), which replaces the CESP areabased approach. Warm Front is a programme specifically targeted at fuel poverty and the associated health risks (Critchley, 2007; Gilbertson, 2006) and includes fabric and heating systems upgrades. This is for vulnerable households; older people, families with children under 5, those certain benefits. 2.3 million upgrades have been delivered by the Warm Front programme (Warm Front Team, 2011). These programmes have created a social housing sector that performs better than average in terms of thermal efficiency. 


\section{METHODOLOGY}

The aim of the Retrofit State of the Nation Survey was to gain an understanding of the current attitudes to and extent of sustainable retrofit in the social housing sector. The survey approach was adopted in order to reach a large sample around the themes identified in table 2. The survey objectives were developed with housing professionals, both consultants and social housing asset managers, who identified key areas of interest. The survey was undertaken with Fusion 21 and Procurement for Housing, social enterprises that deliver procurement services to social housing Registered Providers. The survey is limited to capturing broad attitudes at specific point in time. A follow up study may provide an interesting perspective of the trajectory of these attitudes.

The data was collected through a web-based questionnaire sent to 704 social housing providers who were registered with Procurement for Housing, the largest national procurement body for the sector. There were 130 valid responses, a response rate of $18 \% .19$ responses were rejected for being organisational duplicates, in which case the most complete response was retained. These were converted into a number of questions that were a mixture of multiple choice and Likert Scale responses. There were 20 questions in total covering the following main areas;

Table 2 - Overview of the Question Themes

Here we will discuss the adoption of sustainable retrofit among social housing providers in terms of their perceptions of sustainable retrofit as an issue for the social housing sector, their strategic position and intent and their views on the factors that will inhibit or shape the market.

\section{Respondents}

\section{Responses by Size of RP}

The responses from the sample are shown in Figure 1. The smallest 50\% of Registered Providers manage less than $1 \%$ of the stock, while the largest $18 \%$ of RPs hold $90 \%$ of the total social housing stock (Homes and Communities Agency 2012). The research team felt that the RPs with a larger stock would be more influential in terms of shaping markets, generally having structured asset management programmes and more likely to benefit from market development activity, and therefore, these larger organisations were targeted. Smaller size categories were rolled into the $<250$ category, while the larger categories were made more discrete, based on the advisory panel's experience of the sector. 


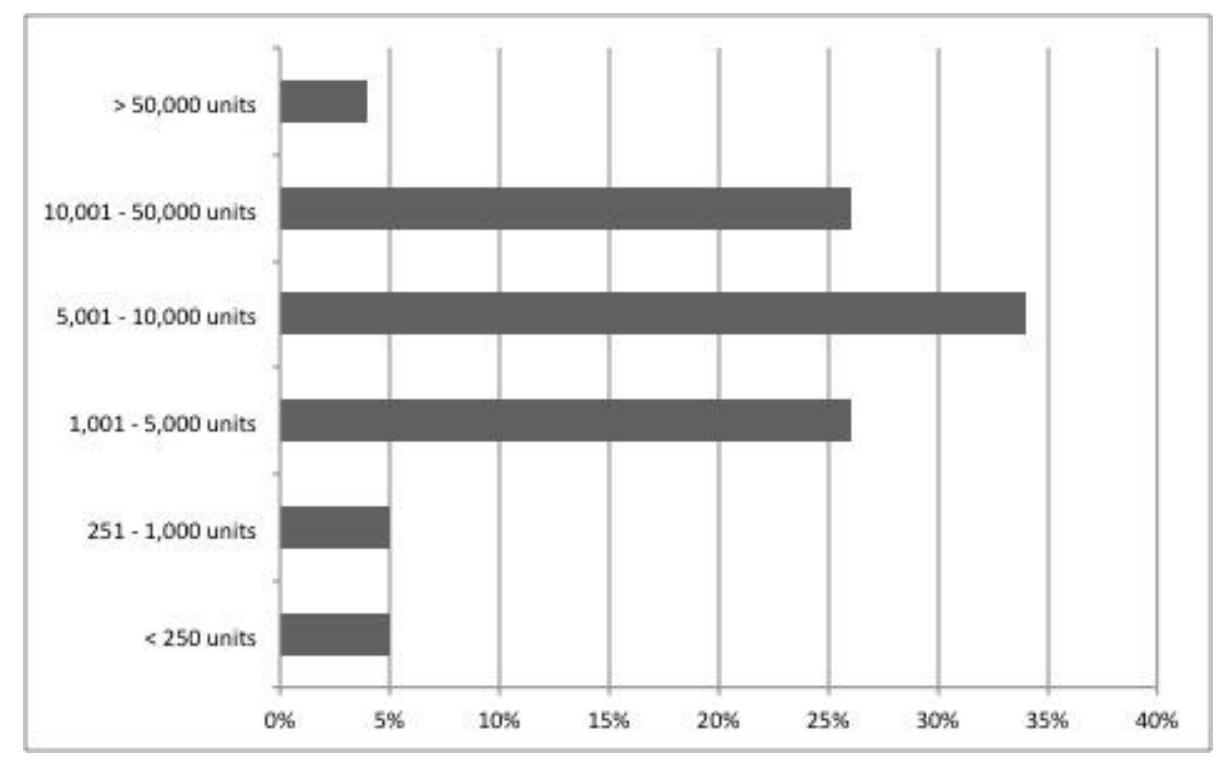

Figure $1-\%$ Responses by Size of Registered Provider

\section{Responses by Region}

The responses by region have a correlation coefficient with the Registered Statistical Return (HCA 2010), a national survey of social housing providers, of 0.85 , indicating that the geographical distribution of the sample is broadly in line with the distribution of Registered Providers nationally, as shown in table 3 . When comparing the responses in the survey with the Registered Statistical Return, 3 regions were over represented by $20 \%$ or more than their expected values; North East, East Midlands and South West. London was the only region that was significantly lower than expected, by $33 \%$. It is not clear why this might be the case, but it might be a factor of the overall sample.

\section{Table 3 - Responses by Region of Operation}

Nine organisations identified themselves as national, while a number of regional organisations identified more than one region, particularly those who identified London, East of England and the South East. Other connected regions, such as South East and South West, East Midlands and East of England, also lead to multiple selections by regional RPs.

\section{Responses by Job Role}

The respondents (Figure 2) were largely from an asset management or managerial background. $62 \%$ of respondents had a technical role in connection with property and asset management, technical or environmental roles. The remainder of the respondents fall into the management/ strategy category covering CEOs, directors, procurement, finance and other managerial roles. 


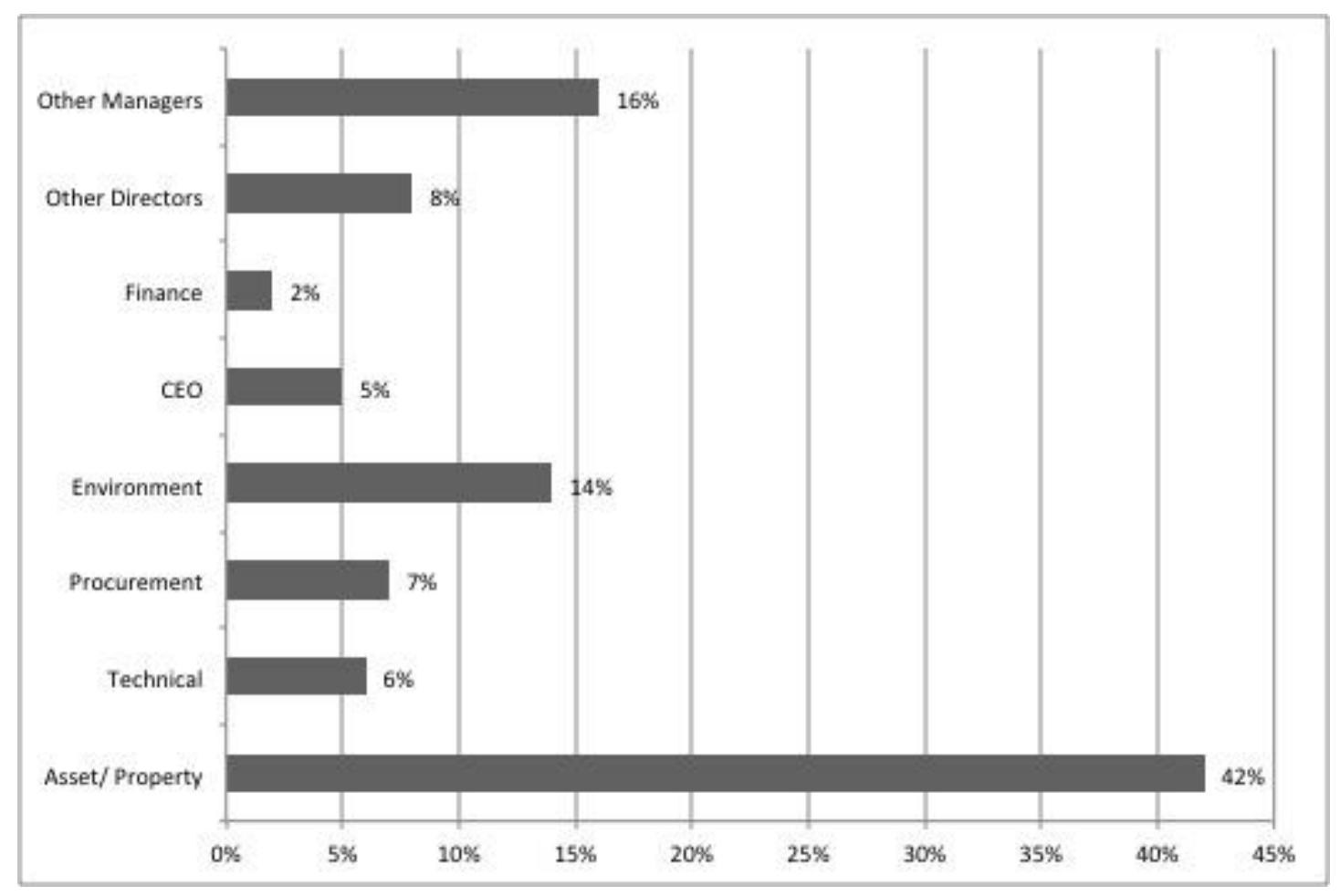

Figure 2 - Responses by Job Role

The responses represent a good sample of the social housing stock in the UK. While this is difficult to put an exact figure on a reasonable estimate might be $20 \%$. It is broadly representative of the larger RPs who will have some capacity to engage with the Retrofit agenda

\section{RESULTS AND DISCUSSION}

The results are discussed in 3 categories of response:

a. Perception of retrofit as a challenge

b. Strategic intent with regards to retrofit

c. Perceived drivers and barriers for the adoption of retrofit.

\section{a. Retrofit as a challenge}

A major factor as to whether social housing will address sustainable retrofit is whether they viewed it as a challenge for the sector as a whole. The question placed the issue of sustainable retrofit within a context of other identified challenges for the social housing sector (Table 4). Sustainable retrofit was identified as the second biggest challenge faced by the social housing providers overall, with 35 responses or $27 \%$ of the sample identifying it as the main challenge. The biggest challenge was the general economic downturn (53 responses or $40 \%$ ), with reduction is benefits (15 responses) and reduced development programme (15 responses) being closely connected with the economic climate. 
Table 4 - Main Challenges Facing the Social Housing Sector

This indicates, that while sustainable retrofit is important, wider economic, social and political issues that shape the broader social housing sector influence the sector just as strongly.

\section{b. Strategic Intent}

The following two questions identified the current strategic position, as well as strategic intent into the future. The organisational response was addressed in identifying the current status of the strategic intent with regards to sustainable retrofit and the future intention.

Table 5 - Current Strategic Position with Regards to Sustainable Retrofit

Table 5 identifies the number of social housing providers who are at different stages of strategic development of a retrofit strategy. This shows a fairly even split of those organisations that have a strategic position (51\%) and those who do not (49\%). A cross tabulation of the data (Table 6) has been undertaken to assess whether those individuals that identified sustainable retrofit as an issue of strategic importance were in organisations that had a developed strategic position. All of the issue categories with 15 or more responses had more than $50 \%$ of the respondents either having an existing strategy or were working towards one, indicating that the fact an organisation was developing a strategy did not necessarily influence the perception of retrofit as the main strategic challenge.

Table 6 - Cross Tabulation of Strategic Readiness and Social Housing Challenge

The relationship between the size of the organisation and the strategic intent with regards to retrofit was considered. The organisational size and strategic intent categories were converted to numeric values ranging from $1-6$ for size of organisation with 1 being the largest, and from 1-5 for strategic intent, with 1 indicating the highest level of readiness. The resulting correlation was 0.236 , indicating no significant relationship between organisational size and current readiness.

The next question looked to identify the organisations strategic intent with regards to retrofit. The results are highlighted in Table 7.

Table 7 - Strategic Intent with Regards to Sustainable Retrofit 
This shows that $74 \%$ of RPs intended to have a strategic plan in place by 2012 . This presents a potential opportunity to follow up this research and assess whether this intent has been followed through by the sector.

\section{c. Drivers and Barriers}

Next the potential drivers and barriers that might influence the adoption of retrofit within the social housing sector were considered. Drivers and barriers for sustainable construction have been identified (Pitt et al, 2009) that focus on policy, financial, knowledge, client demand factors, although these vary depending on the position within the supply chain (Hakkinen and Belloni, 2011). The drivers and barriers identified by the research team and the partners were designed to be specific to social housing providers, but still identified the broad pattern of policy, regulation, clients, knowledge and finance highlighted in wider studies.

\section{Drivers for Retrofit}

The respondents were asked to identify up to 3 issues that they saw as potentially supporting the widespread adoption of sustainable retrofit within the social housing market (Table 8). The main issue is concerned with the financial aspect of sustainable retrofit and the impact it would have on individuals in terms of their financial position ( 88 responses). The related issue of fuel poverty (63 responses) was also a strong driver. This may be considered in terms of policy goals for the RP, but also in terms of sustainable retrofit direct and immediate benefit to residents.

When compared against the issue of climate change (16 responses), fuel poverty and energy bills for residents were seen as substantially stronger drivers. This chimes with a survey of 250 social housing residents undertaken by Chahal et al (2012) where the reasons for adopting energy efficiency were identified. Climate change accounted for only $3.6 \%$ of the responses, while immediate benefits of reduced energy costs (17\%), improved comfort (9\%) and improved health (5\%). It should also be noted that $55 \%$ of the sample in this study, either did not respond to the question $(27 \%)$ or indicated the landlord as the major driver for adoption (28\%). Both studies indicate immediate benefits of sustainable retrofit are the major driver, when compare with more remote issues such as climate change.

Policy was identified as a driver by $43 \%$ of the total sample. This is by no means insignificant, but the role of central Government in shaping the agenda is not seen as perhaps as significant as other issues. At the stage of the survey the Green Deal and Energy Company Obligation (ECO) were in development, but were seen as having traction for the social housing sector. Again, a repeat of the survey, given the more concrete nature of the policy options, would be revealing.

Table 8 - Drivers for Retrofit Adoption 
Organisational factors around both organisational commitment and financial position were both seen as significant drivers for the adoption of retrofit within the social housing market. Taken together, the willingness and financial capacity of social housing providers to respond can be considered a strong driver.

These drivers should be viewed as interlinked. Policy and demands of residents shape organisational response. Issues such as finance, driven by factors as varied as the benefits regime and the ability of providers to access capital markets all influence the position that social housing providers can take when delivering retrofit programmes. These interrelationships mean that policy demands for social housing providers to participate in this market-making role must recognise the broader context in which they operate.

\section{Barriers for Retrofit}

Here, respondents were allowed to identify up to 4 barriers. The biggest barrier is that of effective funding streams for retrofit (Table 9). This was identified by nearly all of the respondents (86\%). This may be addressed by the development of policy instruments such as Green Deal and ECO, but the respondents identify this as the core issue. Indeed, the lack of policy was identified as another key barrier with 47 responses (36\%).

Table 9 - Barriers for the Adoption of Sustainable Retrofit

Organisational commitment and the view of the business case for sustainable retrofit were identified as a barrier with 43 respondents identified organisational commitment as a possible barrier. When compared with their own organisational position with regards to strategic response to retrofit, the respondents that identified organisational commitment as a barrier did not display any significant difference in distribution of strategic position as compared to the whole sample. This potentially means that this response was a perception of the sector as a whole, rather than respondents drawing on their own organisational experience.

The next category was concerned with both internal and external capability to deliver the agenda in terms of knowledge and supply chain readiness. 55\% overall identified a skills and knowledge issue, either internally or within the wider supply chain. In terms of an internal lack of technical knowledge Table 10 identifies the breakdown by size of Registered Provider.

Table 10 - Lack of Technical Knowledge by Size of Organisation

Concentrating on the bulk of the organizations (i.e. the $86 \%$ between 1000 and 50,0000 units) there appears to be little difference in terms of how they viewed their own technical knowledge. Smaller organisations identified the skills and knowledge within the supply 
chains as an issue with repairs and maintenance (21 responses or 16\%), installation (26 responses or $20 \%$ ) and equipment (23 responses or 18\%) supply chains all causing concern for some of the respondents. Overall, $40 \%$ of respondents identified some form of supply chain readiness issue. This should be considered alongside the potential for long-term technical risk, such as defects or non-performance of sustainable retrofit, with 43 responses (33\%). The view of supply chain capability from housing professionals reinforces the need for supply chain development, but it does indicate that during the development phase there are risks associated with engaging with an immature supply chain.

The barriers cannot be considered in isolation from one another. Organisational intent, financing and the capacity to deliver are all interrelated factors. What this identification of the barriers does indicate is that supply chain development is required for the retrofit sector.

\section{CONCLUSIONS}

The findings from the study show that the social housing sector is aware of sustainable retrofit as an issue. There is some strategic intent and a view that the issue is important. A number of linked issues will drive or hamper the desired market formation for sustainable retrofit. The first is policy; the study was during a time of policy uncertainty, which to some extent has been resolved. However, delays with the implementation of certain policy initiatives such as delays to the Green Deal and the Renewable Heat Incentive create uncertainty. If the UK Government wishes to deliver the market transformation it desires, policy uncertainty will need to be reduced. Policy makers must also recognise that decisions with regards to social housing are not made in a vacuum. Decisions that reduce income will impact the ability of social housing providers to engage with the sustainable retrofit agenda. The second issue is the organisational perspective. What are the drivers for individual organisations to engage with the sustainable retrofit agenda? There is a view from the respondents that sustainable retrofit is important, but organisational priorities, the need for a well-defined business case, and access to finance are all facts of life that must be addressed. Social housing providers will not engage in sustainable retrofit if it does not deliver for the organisation and its residents. Finally, in shaping the market, the social housing providers and their residents are taking on risk. Low levels of knowledge concerning sustainable retrofit, in both social housing providers and their supply chains, means that there are risks of nonperformance of installations. This could also mean defects in properties, potentially leading to negative health effects for residents. Social housing providers' first obligation is to their residents. Market making, no matter how desirable for the UK Government, should not be pursued at the risk of residents' health or financial well-being.

The UK Government is asking the social housing sector to take on the risk of engaging with an immature market sector, so that less experienced and well-resourced clients in the private sector can procure more confidently. Social housing, and therefore its residents, will be a testbed for experimentation. If that is the position, then effectively understanding and assessing the barriers for social housing to engage with the kinds of programmes, that will build the desired skills and knowledge, will be required. 


\section{References}

Bell, M. and Lowe, R. (2000) Energy efficient modernisation of housing: a UK case study, Energy and Buildings, Vol. 32, No. 3, pp. 267-280

Boardman, B. (2007). Home Truths: A low Carbon Strategy to reduce UK housing emissions by $80 \%$ by 2050, Oxford: University of Oxford Environmental Change Institute.

Chahal, S., Swan, W. and Brown, P. (2012) Tenant Experiences of Retrofit, Swan, W and Brown, P. (Ed.) Proceedings of Retrofit 2012 January $24^{\text {th }}-26^{\text {th }}$ 2012, University of Salford, Salford

Clapham, D. and Kintrea, K. (1987) Importing housing policy: Housing co-operatives in Britain and Scandinavia, Housing Studies, Vol. 2, No. 3, pp.157 - 169

Communities and Local Government (2006) Code for Sustainable Homes: A step-change in sustainable home building practice, CLG, London

Communities and Local Government (2011) English House Condition Survey, CLG, London,

Critchley, R., Gilbertson, J., Grimsley, M., Green, G., and the Warm Front Study Group (2007) Living in cold homes after heating improvements: Evidence from Warm-Front, England's Home Energy efficiency Scheme, Applied Energy, Vol. 84, No. 2, pp.147 - 158

Department for Energy and Climate Change (2009a) Energy Use in the UK: Domestic Data Tables 2009 Update, available at http://www.decc.gov.uk/en/content/cms/statistics /publications/ecuk/ecuk.aspx (Accessed 23rd December 2009)

Department for Energy and Climate Change and Energy Saving Trust (2011a) Home Energy Pay as You Save Pilot Review, DECC, London

Department for Energy and Climate Change (2011b) Extra help where it is needed: a new Energy Company Obligation, DECC, London

Department for Energy and Climate Change (2012a) Annual report on Fuel Poverty, National Statistics, London

Department for Energy and Climate Change (2012b) Carbon Saving Community: Energy Company Obligation, DECC, London

Department for Trade and Industry (2006) The Energy Challenge, DTI, London 
Department for Trade and Industry (2007) Meeting the Energy Challenge, DTI, London

Druckman, A. and Jackson, T. (2008) Household energy consumption in the UK: a highly geographically and socio-economically disaggregated model. Energy Policy Vol. 36, No. 8, pp. 3177- 3182.

Geels, F. W. (2005) Technical Transitions and Systems Innovations: A Co-Evolutionary and Socio-Technical Analysis, Edward Elgar Publishing, Cheltenham

Gilbertson, J., Stevens, M., Stiell, B. and Thorogood, N. (2006) Home is where the hearth is: Grant recipients' views of England's Home Energy Efficiency Scheme (Warm Front), Social Science and Medicine, Vol. 63, No. 4, pp. 946-956

Government Office for Science (2008) Powering Our Lives: Sustainable Energy Management and the Built Environment, GoFS, London

Guertler, P. (2012) Can the Green Deal be fair too? Exploring new possibilities for alleviating fuel poverty, Energy Policy, No. 49, pp. 91 - 97

Häkkinen, T. and Belloni, K. (2011) Barriers and drivers for sustainable building, Building Research and Information, Vol. 39, No. 3, pp. 239-255

HM Government (2008) Climate Change Act, HM Government, London

HM Government (2010a) Warm Homes, Greener Homes: A Strategy for Household Energy Management, DECC, London

HM Government (2010b) Low Carbon Construction Innovation and Growth Team Final Report, Department of Business Innovation and Skills, London

Homes and Communities Agency (2012) Statistical Data Return 2011-12, HCA, London

Hong, S., Oreszczyn, T., Ridley, I. and Warm, Front Study Group (2006) The impact of energy efficient refurbishment on the space heating fuel consumption in English dwellings. Energy and Buildings, Vol. 38. No. 10, pp. 1171-1181.

Hong, S.H., Gilbertson, J., Oreszczyn, T., Green, G., Ridley, I. and the Warm Front Study Group (2009) A field study of thermal comfort in low-income dwellings in England before and after energy efficient refurbishmente. Building and Environment, Vol. 44, No. 6, pp. $1228-1236$.

Jenkins, D. P. (2010) The value of retrofitting carbon-saving measures into fuel poor social housing, Energy Policy, Vol. 38, No. 2, pp. 832 - 839 
Kelly, M.J. (2009) Retrofitting the existing UK building stock, Building Research and Information, Vol. 37, No. 2, 196-200

Killip, G. (2012) Beyond the Green Deal: Market Transformation for low carbon housing refurbishment in the UK, Swan, W and Brown, P. (Ed.) Proceedings of Retrofit 2012 January $24^{\text {th }}-26^{\text {th }} 2012$, University of Salford, Salford

Lowe, R., Oreszczyn, T. (2008) Regulatory standards and barriers to improve performance for housing, Energy Policy, Vol. 36, No. 12, pp. 4475 - 4481

North Irish Housing Executive (2012) 2011 House Condition Survey Preliminary Findings, NIHE, Belfast

Office of the Deputy Prime Minister (2006) The Building Regulations 2000: Approved Document L1B, ODPM, London

Pitt, M., Tucker, M., Riley, M. and Longden, J. (2009) Towards sustainable construction: promotion and best practices, Construction Innovation: Information, Process, Management, Vol. 9, No. 2, pp. $201-224$

Power, A. (2008) Does demolition or refurbishment of old and inefficient homes help to increase our environmental, social and economic viability? Energy Policy, Vol. 36, No. 12, pp. 4487-4501

Van Sandick, E, and Oostra, M. (2010) Upscaling Energy Related Innovations, Barrett, P. (Ed) CIB World Building Congress Task Group 66, CIB, 10th - 13th May 2010, pp. 95 - 114

Ravetz, J. (2008) State of the stock - What do we know about existing buildings and their future prospects? Energy Policy, Vol. 36, No. 2, pp. $4462-4470$

Reeves, A., Taylor, S., and Fleming, P. (2009) Deep carbon emission reductions in existing UK social housing: are they achievable and how can they be funded, European Council for an Energy Efficient Economy, Summer Study, $1^{\text {st }}-6^{\text {th }}$ June 2009, France, pp. 919-930

Roberts, S. (2008) Altering Existing Buildings in the UK, Energy Policy, Vol. 36, No. 2, pp. $4482-4486$

Scottish Government (2012) Housing Statistics for Scotland: Key Information and Summary Tables, Scottish Government, Edinburgh

Swan, W., Wetherill, M. and Abbott, C., (2010) A Review of the UK Domestic Energy System, University of Salford, Salford 
Swan, W., Abbott, C. and Barlow, C. (2012) ApRemodel: A Study of Non-Technical Innovation in Multi-Occupancy Sustainable Retrofit Housing Projects, Swan, W and Brown, P. (Ed.) Proceedings of Retrofit 2012 January $24^{\text {th }}-26^{\text {th }}$ 2012, University of Salford, Salford

Technology Strategy Board, (2009) Retrofit for the Future: Competition for Development Contracts, available at, http://www.innovateuk.org/competitions/retrofit-for-the-future.ashx, (accessed January 11, 2010)

Warm Front (2011) Connecting with Communities: The Warm Front Annual Report 2010/11, The Warm Front Team, Newcastle

Welsh Assembly Government (2011) Statistical Release: Dwelling Stock Estimates for Wales, Statistics for Wales, Cardiff

Wetherell, S., Hawkes, J. (2011). Are SAP based assessments an accurate way of predicting the energy savings made through refurbishment?, Chiang, T. and Moran, F. (eds.) Buildings don't use energy, people do? Research Students' Conference on Domestic Energy Use and CO2 Emissions in Existing Dwellings. Bath: EDEn, University of Bath, pp. 43-54

Wetherill, M., Swan, W., Abbott, C. (2012) The influence of UK energy policy on low carbon retrofit in UK housing, Swan, W and Brown, P. (Ed.) Proceedings of Retrofit 2012 January $24^{\text {th }}-26^{\text {th }} 2012$, University of Salford, Salford 